\title{
PIMPINAN MTI TABEK GADANG PADANG JAPANG DARI MASA KEMASA
}

\author{
Hariadi \\ BPNB PADANG \\ Jl. Raya Belimbing No. 16 A Kuranji Padang
}

\begin{abstract}
Abstrak
Tulisan ini menjelaskan para pimpinan MTI Tabek Gadang dari masa ke masa. Diantara alasan yang melatarinya adalah perjalanan panjang dan pergantian kepemimpinan yang telah silih berganti. Penelitian ini adalah penelitian kwalitatif dengan pendekatan penulisan biografi. Beberapa hasil yang terungkap pemimpin MTI Tabek Gadang semenjak berdiri sampai penelian ini telah silih berganti beberapa orang pemimpin. Pemimpin terdiri dari keturunan dan alumni MTI Tabek Gadang.
\end{abstract}

Kata kunci: MTI Tabek Gadang, Padang Japang

\section{A. PENDAhULUAN}

Madrasah Tarbiyah Islamiyah Tabek Gadang Padang Japang telah berumur lebih satu abad. Lembaga pendidikan ini pada awalnya adalah sebuah lembaga pendidikan surau yang didirikan oleh Abdul Wahid. Surau tersebut dalam perjalanannya bertransformasi menjadi madrasah yaitu Madrasah Tarbiyah Islamiyah.

Madrasah ini terletak di Nagari Tujuah Koto Talago, yang secara administrasi pemerintahan merupakan bagian dari kecamatan Guguk Kabupaten Lima Puluh Kota Provinsi Sumatera Barat (Data Potensi Nagari, 2010). Nagari ini merupakan salah satu nagari yang menjadi pusat pendidikan Islam di Luak (Luhak) Limo Puluah semenjak pra kemerdekaan. Hal tersebut karena berdirinya beberapa sekolah agama lainnya seperti Darul Funun Abbasiyah yang didirikan oleh Syekh Abbas Abdullah dan Nahdhatun Nisaiyyah. Madrasah Tarbiyah Islamiyah dan Darul Funun masih berdiri sampai hari ini.

Madrasah Tarbiyah Tabek Gadang dalam perjalanannya telah melewati pelbagai situasi zaman, zaman penjajahan Jepang, Belanda, dan melewati pergolakan dalam negeri, situasi politik dan pengaruh modernisasi. Namun demikian, Madrasah Tarbiyah Islamiyah Tabek Gadang tetap berdiri sampai hari ini, disaat banyak sekolah sejenis sudah tutup dan tinggal kenangan. Salah satu faktor yang membuat Madrasah Tarbiyah Islamiyah Tabek Gadang tetap berdiri adalah estafet kepemimpinan yang terus berlanjut.

Pemimpin dalam sebuah organisasi sangat penting artiya, maju mundurnya sebuah organisasi sangat bergantung kepada sejauh mana seorang pemimpin mampu memanajemeni lembaga yang dipimpinnya. Dalam organisasi yang bersifat tradisional, sosok pemimpin sangat berpengaruh dan sentral. 


\section{B. METODOLOGI}

Penelitian ini adalah penelitian kualitatif, dan pemilihan jenis penelitian kualitatif ini dimaksudkan untuk melakukan pengumpulan dan penggalian nilai dari objek Penelitian. Penelitian ini menggunakan pendekatan penulisan biografi. Kata biografi berasal dari bahasa Yunani yaitu bios yang berarti hidup dan kehidupan sedangkan grafi atau graphien berarti menulis atau penulisan. Jadi esensi dari biografi adalah penulisan riwayat hidup seseorang (Sagimun MD 1993: 36)

Teknik pengumpulan data dari kegiatan penelitian ini adalah sebagai berikut :

Studi kepustakaan merupakan aktifitas mengumpulkan tulisan-tulisan yang berkaitan dengan topik bahasan yang tersebar di berbagai pustaka ataupun koleksi pribadi. Bentuk-bentuk dokumen yang dikumpukan adalah buku, majalah, artikel, koran dan dokumen-dokumen lainnya.

Wawancara merupakan proses interaksi dan komunikasi antara peneliti dengan responden. Wawancara juga dapat diartikan sebagai model pengumpulan data dengan cara bertanya langsung kepada responden dan jawaban-jawaban dicatat atau direkan dengan alat bantu perekaman.( Kusmayadi 2000:84)

Data yang terkumpul diolah dengan langkah-langkah sebagai berikut: mengorganisasikan data, memilah data menjadi satuan, mensintesiskan, mencari dan menemukan pola, dan menemukan apa yang penting dan apa yang perlu dipelajari dan terakhir memutuskan apa yang dapat dan perlu diceritakan kepada orang lain. (S.Wiranta dan H.Hadisuwarno, 2007: 15-16). Bagian penting dari pengolahan data adalah analisa data. Data yang terkumpul dapat diberi arti untuk memecahkan masalah penelitian. Data yang telah melalui proses pengolahan data disusun menjadi laporan penelitian dalam bentuk deskriptif analisis.

\section{PEMBAHASAN}

Selama seratus tahun lebih MTI Tabek Gadang telah memberikan sumbangsih terhadap kemajuan pendidikan anak bangsa. Sepanjang perjalanannya estafet kepemimpinan MTI Tabek Gadang terus silih berganti. Tulisan ini mendeskripsikan pimpinan MTI Tabek Gadang dari masa ke masa.

1. Syekh Abdul Wahid Ashshalihy

a. Kelahiran

Abdul Wahid lahir di Padang Japang, pada bulan Muharam tahun $1295 \mathrm{H}$, yang bertepatan dengan tahun 1878 M. Ayah beliau bernama Syekh Muhammad Shaleh, seorang ulama dari Padang Kandis, Tujuh Koto Talago. sedangkan ibu beliau berasal dari suku Sikumbang Padang Japang Tujuah Koto Talago. Saudara ayah beliau juga seorang pemuka agama pada masanya yang terkenal dengan Buya Munggu. 
b. Pendidikan

Abdul Wahid kecil mengawali pendidikan agamanya kepada Syekh Muhammd Saleh yang merupakan ayahnya. Setelah mendapatkan dasar pendidikan agama, beliau kemudian melanjutkan pendidikan kepada Syekh Engku Mudo Amran dan Engku Meran di Limbukan Payakumbuh. Beberapa tahun belajar di Limbukan beliau pindah ke Sungayang di Tanah Datar, untuk menuntut ilmu kepada Syekh Thaib Umar. Guru beliau yang lainnya adalah Syekh Abdul Hamid di Tanjung Ipuh, Tujuh Koto Talago. Mengenai ilmu tasawuf Abdul Wahid belajar kepada Syekh Muhammad Sa'ad di Mungka, yang terkenal dengan sebutan Beliau Surau Baru. ${ }^{1}$

Abdul Wahid muda tumbuh dalam cinta terhadap ilmu pengetahuan. Hal tersebut tentu saja dipengaruhi oleh lingkungan keluarga beliau yang juga mencintai ilmu pengetahuan. Buah dari kesungguhannya itu, Abdul Wahid dikenal sebagai seseorang yang luas ilmu agamanya.

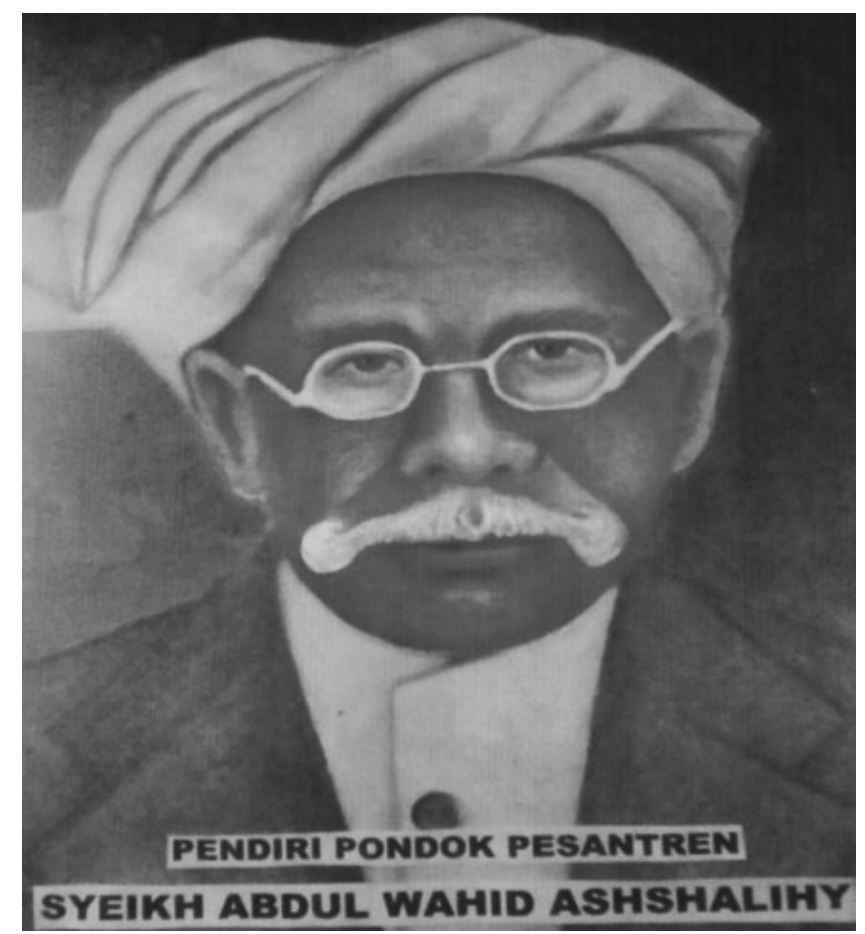

Gambar 1
Pendiri MTI Tabek Gadang

Pada tahun 1919 Abdul Wahid berangkat ke Makkah untuk menunaikan ibadah haji dan menuntut ilmu disana. Periode dari tahun 1919 sampai tahun 1922, Abdul Wahid menuntut ilmu di Makkah kepada Syekh Hasan Yamani dan Syekh Sayyid 'Ali Al-Maliki. Disamping ilmu syariat, ilmu tasawuf juga beliau perdalam selama berada di Makkah.

c. Kiprah Abdul Wahid pada Dunia Pendidikan

Kiprah Abdul Wahid dalam dunia pendidikan diwujudkannya dengan mendirikan sebuah surau di Padang Japang, didekat sebuah kolam besar (tabek). Surau tersebut kemudian dikenal dengan nama Surau Tabek Gadang yang merupakan cikal bakal MTI Tabek Gadang.

\footnotetext{
${ }^{1}$ Wawancara dengan Fakhrurrazi
} 
Syekh Abdul Wahid Ashshalihy telah banyak berkiprah dalam rangka mengembangkan pengajaran Islam melalui dakwah Islam ke tengah-tengah masyarakat serta berbagai upaya untuk mengembangkan lembaga pendidikan agama. Berbagai metode dan cara beliau lakukan untuk mewujudkan pola hidup dan pergaulan yang dilandasi dengan nilai-nilai Islam. Usahausaha yang dilakukan oleh Syekh Abdul Wahid untuk mewujudkan kemajuan dalam kehidupan beragama sebagai berikut:

1. Mencetak kader-kader ulama dan pemimpin umat. Sebagai pendiri MTI Tabek Gadang beliau telah banyak membina anak didiknya agar mempunyai bekal untuk menjadi pimpinan ummat. Murid-murid beliau berasal dari pelbagai daerah di Sumatera Barat, dan juga diluar Sumatera Barat. Selama lebih kurang 45 tahun Syekh Abdul Wahid mengabdikan dirinya. Sebagai pemimpin beliau dikenal bijaksana, suka bekerja keras dan memiliki pengetahuan yang luas. Anak didik yang beliau asuh sudah banyak yang menjadi ulama dan intelektual muslim.

2. Mengadakan wirid pengajian. Sebagai seorang yang terpandang terutama tentang kedalaman ilmu agamanya, beliau sering melaksanakan kegiatan dakwah Islam, disamping aktif memberikan pelajaran agama kepada anak didiknya melalui lembaga pendidikan yang beliau pimpin. Wirid pengajian yang beliau terapkan bagi anggota masyarakat yang berminat bertempat di surau suluk. Ia menyampaikan pegajiannya dalam bentuk halaqoh dengan materifiqih, akidah, tasawuf, tauhid, tafsir, dan hadis. Dakwah yang beliau sampaikan tidak hanya di surau madrasah, akan tetapi beliau juga menyempatkan diri untuk mengunjungi masyarakat, bahkan sempat memberikan pengajian di surau Inyiak Candung. Hubungan kedua ulama ini sangat dekat, seperti orang yang bersaudara, keduanya saling mengunjungi. Inyiak Candung pun sering diundang ke Tabek Gadang untuk menyampaikan pengajian agama kepada masyarakat yang dibina Syekh Abdul Wahid.

3. Mengadakan Suluk. Pengembangan dan pendalaman ajaran Islam kepada masyarakat beliau lakukan melalui suluk di bulan Ramadhan. Surau dipenuhi orang-orang yang ingin memperdalam dan berpegang teguh pada ajaran Islam, beliau lakukan dengan Thareqad Naqhsyabandiyah dan latihan kerohanian seperti zikir, dan doa. Murid-murid yang sampai kepada tingkat yang diharapkan maka diberi izin untuk membuka sura suluk, yang lebih sering dikenal dengan sebutan khalifah suluk, suatu gelar yang diberikan karena seseorang yang dianggap telah layak dan mendapatkan ijazah dalam masalah suluk dan tareqad (Mulyadi, 2010)

Uraian di atas memberikan suatu gambaran tentang usaha-usaha dan pendekatan yang dilakukan oleh Abdul Wahid untuk mendakwahkan agama secara luas, dengan harapan dapat menegakkan kebenaran dan mencegah kemungkaran di tengah-tengah masyarakat.

\section{d. Keluarga}

Sebagaimana kebanyakan ulama pada zamannya, Syekh Abdul Wahid mempunyai beberapa istri. Hal tersebut dimungkinkan karena pandangan positif masyarakat terhadap seorang 


\begin{tabular}{|c|c|c|c|}
\hline NO & NAMA ISTRI & $\overline{\text { ASAL }}$ & ANAK \\
\hline 1 & Raanah & Padang Kandis & $\begin{array}{l}\text { - Rawanis } \\
\text { - Rabiah } \\
\text { - M. Asih }\end{array}$ \\
\hline 2 & Qamariah & Koto Kociak & - \\
\hline 3 & Maraya & Ampang Gadang & $\begin{array}{l}\text { - Lawana } \\
\text { - Dumairi }\end{array}$ \\
\hline 4 & Fatimah & Ampang Gadang & $\begin{array}{l}\text { - Wahdiar Wahid } \\
\text { - Wardi Wahid }\end{array}$ \\
\hline 5 & Nuriah & Padang Japang & - Kani'ah \\
\hline 6 & Mariyah & Padang Japang & $\begin{array}{l}\text { - Anwar Dt. Sangkuno } \\
\text { - Nurah } \\
\text { - Upik } \\
\text { - Asyiah. }\end{array}$ \\
\hline 7 & Railah & Padang Japang & - Darianih \\
\hline 8 & Jawa & $\begin{array}{l}\text { Koto Tangah } \\
\text { Simalanggang }\end{array}$ & $\begin{array}{l}\text { - Syarkawy A.W } \\
\text { - Nurana } \\
\text { - Khairani } \\
\text { - Suhaimi A.W }\end{array}$ \\
\hline 9 & Marab & Tanjung Jati & - Nurma \\
\hline 10 & Saniah & Sungai Kumayang & - Asmuni Dt. Parmato \\
\hline 11 & Fatimah anak & $\begin{array}{l}\text { Situjuah Bandar } \\
\text { Dalam }\end{array}$ & $\begin{array}{l}\text { - Nuriani } \\
\text { - Man } \\
\text { - M. Nizam }\end{array}$ \\
\hline
\end{tabular}

ulama. Orang tua dan seorang perempuan merasa terhormat bila bermenantu dan bersuamikan seorang ulama. Harapan lainnya adalah akan melahirkan keturunan yang sholeh. Berikut adalah nama istri, asal dan putra-putri beliau:

Sebagai ulama, Syekh Abdul Wahid adalah ahli Thareqad Naqsabandiyah yang melanjutkan perjuangan dari orang tuannya yaitu Syekh Muhammad Sholeh. Oleh karena itu beliau aktif dalam mengajarkan ilmu syariah agama, dan juga aktif sebagai Mursyid yang memimpin suluk untuk orang-orang yang mengamalkan Thareqad Naqsabandiyah (Mulyadi, 2005).

\section{e. Peranan dalam Mendirikan MTI Tabek Gadang}

Sebagaimana sudah disinggung sebelumnya, bahwa cikal bakal MTI Tabek Gadang adalah Surau yang beliau dirikan. Perjalanan madrasah ini, baik fisik maupun non fisik sangat dipengaruhi oleh ide dan gagasan beliau. Perubahan besar yang beliau gagas adalah sewaktu menyepakati bersama ulama lainnya perubahan sistem pembelajaran dari halaqoh ke sistem klasikal. Dengan demikian murid-murid dibagi perlokal berdasarkan tingkatan.

2. Syarkawi Abdul Wahid

Pasca meninggalnya Syekh Abdul Wahid, pada tahun 1950 kepemimpinan MTI Tabek Gadang dilanjutkan oleh anaknya, Syarkawi Abdul Wahid. Syarkawi Abdul Wahid adalah 
anak kandung Syekh Abdul Wahid dari pekawinannya dengan istrinya yang bernama Jawa berasal dari Koto Tangah Simalanggang. Sewaktu Syarkawi Abdul Wahid menerima estafet kepemimpinan, kondisi MTI Tabek Gadang baru aktif kembali setelah agresi Belanda. Disamping menjalankan proses belajar mengajar, Syarkawi mengusahakan agar fisik madrasah semakin baik, terutama ruang belajar.

Berkaitan dengan fisik sekolah Syarkawi dengan pengurus MTI lainnya menggagas untuk mendirikan tambahan lokal belajar di tepi jalan yang berdekatan dengan surau. Lokal sebelumnya, terpisah oleh luasnya Tabek Gadang (kolam besar). Usaha penambahan lokal tersebut dilaksanakan pada tahun 1955. Lokasi tiga lokal tambahan tersebut berada diatas tebing dekat rumah tempat tinggal Syekh Abdul Wahid. Proses membangun ruang belajar tersebut diawali dengan meruntuh dan mendatarkan tebing tersebut yang dilakukan secara gotong royong oleh masyarakat dan para santri, siang dan malam hari. Sedangkan untuk pendanaan pembangunan dimintakan sumbangan dari masyakat. Berkaitan dengan hal itu, Nasri Bey menceritakan; "Kami mencari dana untuk membuat sekolah dan melaksanakan goro mendatarkan perumahan sekolah, ada orang yang meragukan kemampuan para siswa dan pengurus dengan ucapan " kalaulah mampu Haji kawi mendatarkan bukit itu, potong kaki saya". ${ }^{2}$

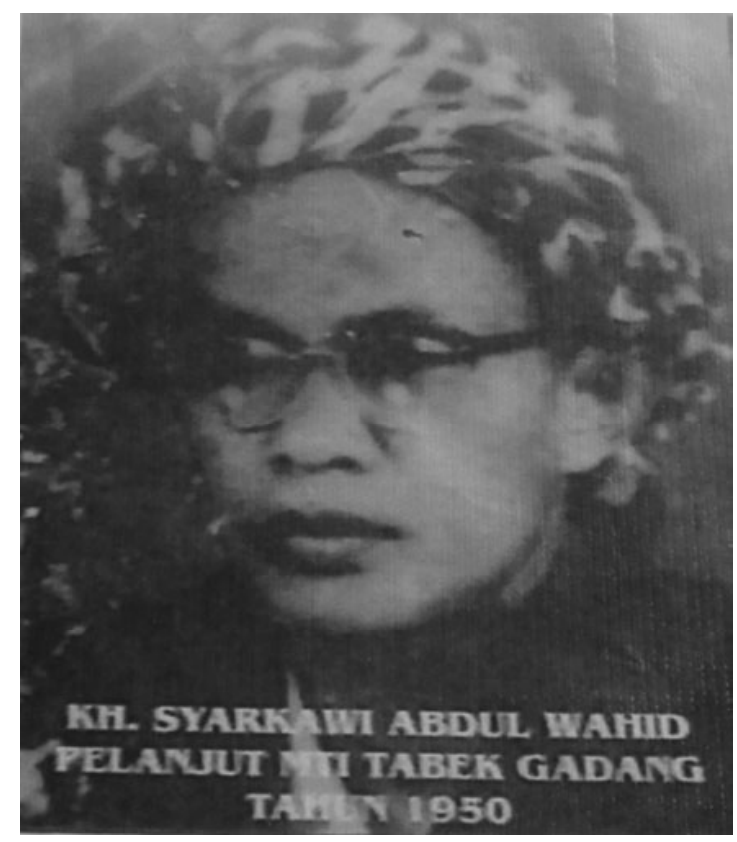

Gambar 2

Pimpinan MTI Tabek Gadang pada tahun 50 an

Dengan adanya tambahan lokal baru tersebut fasilitas belajar mengajar semakin lengkap. bangunan lama tetap dimanfaatkan sebagian ruang belajar dan wirid mingguan. Penambahan lokal pada saat itu karena pertambahan murid yang belajar mengalami peningkatan. Akan tetapi

\footnotetext{
${ }^{2}$ Wawancara dengan Nasri Bey pada bulan Juni 2013 di Sipingai
} 
akhir tahun 50-an dan awal tahun 60-an jumlah murid mengalami penurunan karena terjadi pergolakan PRRI.

Setelah pergolakan reda, Syarkawi bersama beberapa muridnya, diantaranya Nasri Bey Kembali memulai proses belajar mengajar setelah mendapat izin dari Panglima Kodam 17 Agustus Sumatera Barat Pada tanggal 1 Maret 1963. Setahun berjalan, pada tahun ajaran 1964/ 1965 muridnya sudah berjumlah 67 orang dan tahun berikutnya semakin meningkat menjadi 167 orang (Mulyadi, 2005). Murid-murid MTI Tabek Gadang berdatangan dari penjuru Sumatera Barat dan daerah sekitarnya. Kepemimpinan Syarkawi Abdul Wahid berakhir dengan berpulangnya beliau kepada sang pencipta pada tanggal 15 Maret 1978 dan dimakamkan di kompleks MTI Tabek Gadang.

Masa awal kepemimimpinan Syarkawi Abdul Wahid, dia banyak dibantu oleh Rusli Abdul Wahid. Rusli Abdul Wahid adalah murid dan menantu dari Syekh Abdul Wahid. Syekh Abdul Wahid menempatkan Rusli sebagai murid yang istimewa, sehingga beliau mengizinkan untuk memakai Abdul Wahid di belakang namanya, sehingga Rusli dikenal dengan nama Rusli Abdul Wahid. Peran Rusli Abdul Wahid dalam mengembangkan MTI Tabek Gadang direalisasikan sebagai guru di MTI Tabek Gadang serta menyampaikan dakwah ke tengahtengah masyarakat. Keberadaan di MTI membawa perkembangan dan kemajuan yang cukup berarti. Mengenai kepribadian Rusli Abdul Wahid sebagai seorang guru, Mulyadi (2005) menuliskan; "Sebagai salah seorang guru di madrasah ini beliau menjadi panutan bagi muridnya, teguh dalam pendirian, kecerdasan dan keteladanan yang beliau miliki menimbulkan kesan simpatik ketika mengajar dan bergaul".

Rusli Abdul Wahid juga merupakan salah satu sumbangan MTI Tabek Gadang terhadap bangsa Indonesia, hal itu dapat diketahui dari perannya diberbagai posisi. Berkaitan hal ini, Amrialis Imam menceritakan:

Rusli Abdul Wahid juga seorang pejuang, beliau bukan hanya saja seorang guru dan pendakwah. Kontribusi beliau dalam perjuangan kemerdekaan cukup banyak. Banyak andil dan peran beliau sebelum dan setelah Indonesia merdeka. Rusli telah aktif dipelbagai peristiwa yang menjadi tonggak-tonggak perjalanan bangsa, mulai dari semaraknya gema sumpah pemuda, zaman Penjajahan Jepang, agresi Belanda dan perisiwa penting lainnya. ${ }^{3}$

Rusli Abdul Wahid juga seorang aktifis politik dan sosial. Ia berperan besar mengelola PERTI dari hanya organisasi bergerak di bidang pendidikan dan dakwah kepada organisasi yang tujuannya lebih luas termasuk bidang sosial politik. Saat itu terjadi dinamika dalam organisasi, ada yang setuju dengan perubahan dan ada juga yang menolaknya. Namun akhirnya diambil jalan tengah berdasarkan usulan dari Syekh Abdul Wahid dan Rusli. Jalan tengah tersebut adalah menjadikan PERTI sebagai organisasi yang bersifat sosial Islam dan menjadikan pendidikan sebagai program unggulan.

\footnotetext{
${ }^{3}$ Wawancara dengan Amrialis Imam
} 


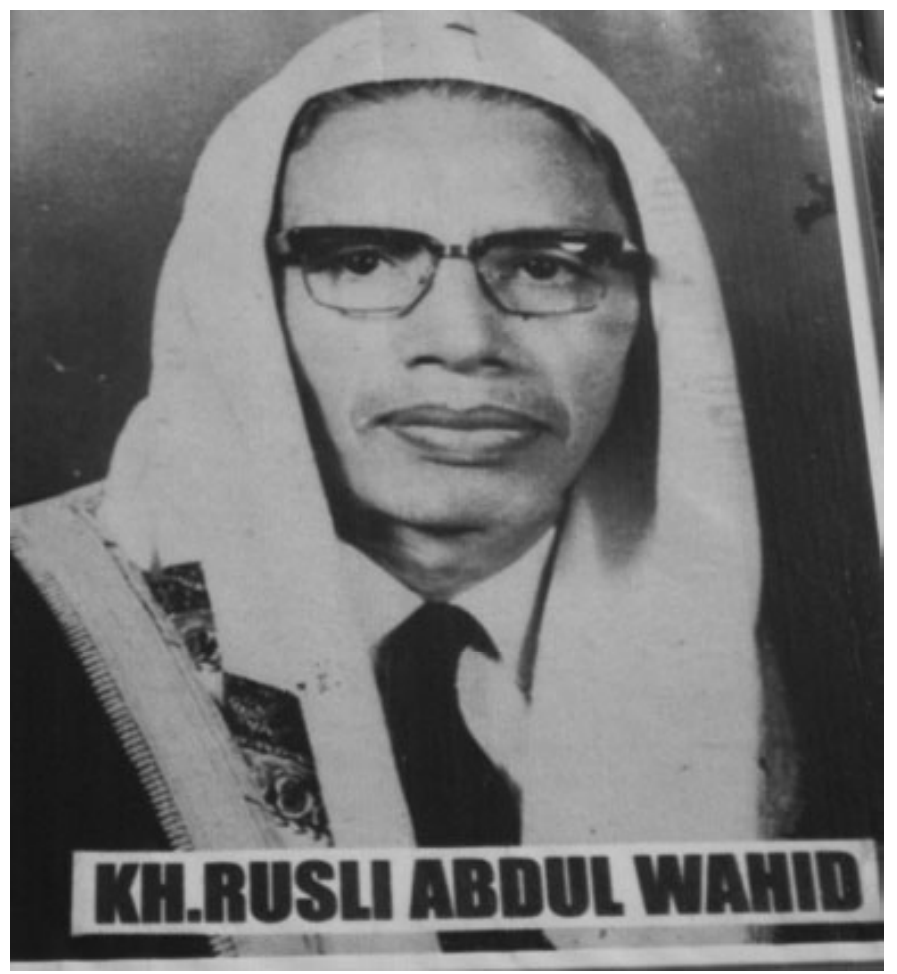

Gambar: 3

Alumni MTI Tabek Gadang

Karir Rusli dalam bidang sosial politik berawal dari memimpin PERTI (Persatuan Tarbiyah Islamiyah). Organisasi ini pertama kali berdiri pada tanggal 5 Mei 1928 di surau Buya Sulaiman Al Rusuli di Candung Bukittinggi oleh ulama penganut paham Ahli Sunnah Wal Jamaah. Awal berdirinya organisasi ini ditujukan untuk pembaharuan di bidang pendidikan Islam dengan menjadikan madrasah sebagai sentralnya. Pada saat pertemuan tersebut Rusli turut hadir mendampingi Syekh Abdul Wahid.

Perkembangan selanjutnya ada tokoh PERTI yang menginginkan organisasi tersebut tidak hanya bergerak di bidang pendidikan semata, tapi juga bergerak pada sosial kemasyarakatan. Gagasan tersebut tidak bisa diterima oleh sebagian tokoh PERTI pada masa terjadinya perbedaan pendapat mengenai corak organisasi PERTI. Pada perbedaan pendapat tersebut transisi dilaksanakan. Saat itu Rusli terpilih sebagai ketua. Kepengurusan baru berusaha melakukan berbagai usaha untuk mempertahankan kesatuan organisasi.

Pertemuan PERTI dibawah pimpinan Rusli digelar di Surau Gading Kenagarian Mungka yang dihadiri banyak delegasi dari cabang-cabang dan ranting, serta para ulama dan tokoh masyarakat. Beberapa keputusan penting dari pertemuan tersebut sebagai berikut:

1. Mengenai nama, tetap mengambil nama bentukan Candung yaitu Persatuan Tarbiyah Islamiyah, yang disingkat dengan PERTI bukan PTI.

2. Dari segi sifat organisasi, bukan semata-mata organisasi persekolahan akan tetapi ditingkatkan menjadi organisasi sosial Islam yang bergerak di bidang dakwah, amal sosial dan pendidikan Islam. 
3. Kepengurusan voorziter dipegang oleh H. Rusli yang dibantu H. Syarkawi sebagai vicevoorziter.

4. Bertindak sebagai penasehat adalah Maulana Syekh Abdul Wahid Ashshalihy dibantu oleh Almukarram Syekh Abdullah H Muhammad Jamil Saadi dan ulama-ulama Sunni terkemuka lainnya.

5. Sekretariat untuk sementara ditetapkan di Surau Baru Mungka.

6. Peresmian berdirinya PERTI diadakan pada tanggal 12 Syawal $1352 \mathrm{H}$ yang bertepatan pada tanggal 28 Januari 1934 di Surau Baru Mungka. (Mulyadi, 2005)

Organisasi ini mendapat sambutan yang positif, hanya dalam waktu dua tahun anggota yang terdaftar lebih dari 700 orang. Pergerakan organisasi selanjutnya semakin meningkat dengan beberapa bidang sebagai konsentrasi tugas, dilandasi oleh semangat persatuan dan kebersamaan, dibidang pendidikan atau sekolah didirikan madrasah di setiap cabang yang terdiri dari beberapa angkatan. Untuk tingkatan lebih tinggi atau Aliyah dipusatkan di Madrasah Tarbiyah Islamiyah Tabek Gadang.

Rusli juga sangat gencar melakukan kegiatan-kegiatan dakwah ke daerah-daerah serta memperkenalkan fungsi madrasah kepada jamaah beliau. Walaupun kesibukan di organisasi dan dalam berdakwah di tengah-tengah mayarakat, beliau tetap menyediakan waktu untuk mengajar anak didiknya di MTI Tabek Gadang. Semangat santri-santri juga sangat tinggi untuk belajar dan berdiskusi dengan H. Rusli. Berkat keteladanan H.Rusli mengantarkan Madrasah Tarbiyah Islamiyah mencapai kejayaan. Rintangan yang dihadapi tidak menjadikan beliau berputus asa, beliau memakai konsep “dimana ada kemauan di situ jalan”. Posisi-posisi penting yang pernah dijabat oleh Rusli Abdul Wahid antara lain sebagai Menteri Urusan Irian Barat dalam kabinet Ali Sostroamidjojo II pada tahun 1956-1957. Kabinet ini merupakan pengganti Kabinet Baharuddin Harahap (Mulyadi, 2005:).

\section{Yusri Anwar}

Pasca meninggalnya Syarkawi Abdul Wahid proses belajar dan mengajar di MTI Tabek Gadang mengalami kemunduran, dan sampai akhirnya madrasah tutup. Beberapa orang murid yang ada dipindahkan ke Madrasah Tarbiyah Islamiyah Koto Panjang Lampasi. ${ }^{4}$ Setelah beberapa tahun tidak berproses beberapa orang alumni MTI Tabek Gadang, pemuka masyarakat dan keturunan Syekh Abdul Wahid mengusahakan untuk kembali menghidupkan proses belajar dan mengajar. Keturunan Syekh Abdul Wahid yang perannya cukup besar adalah Yusri Anwar.

Yusri Anwar adalah cucu dari Syekh Abdul Wahid dari istri beliu yang bernama Mariyah yang berasal dari Padang Japang. Peran Yusri Anwar terlihat pada usahanya untuk kembali menghidupkan proses belajar mengajar yang sudah terhenti beberapa tahun lamanya. Posisi beliau yang menjabat sebagai kepala Kantor Departemen Agama Kabupaten Lima Puluh Kota memberikan peluang yang cukup luas untuk memperhatikan MTI Tabek Gadang. Dengan

\footnotetext{
${ }^{4}$ Wawancara dengan Amrialis Imam dan Nasri Bey
} 
berbagai usaha akhirnya Yusri Anwar dan beberapa orang lainnya proses belajar mengajar dapat kembali dilaksanakan di MTI Tabek Gadang pada akhir tahun 1980 an.

Pengabdian beliau terhadap madrasah yang didirikan oleh kakeknya tidak berlangsung lama, sedang giat-giatnya memajukan madrasah beliau dipanggil oleh yang Maha Kuasa. Mengenai meninggalnya Yusri Anwar, Mulyadi menuliskan sebagai berikut:

Disuatu ketika beliau sedang menulis konsep doa yang akan dibaca pada acara kedatangan Menteri Koperasi RI Bustamil Arifin. Sebagai Kepala Kantor Departemen Agama, pembacaan doa diamanahkan kepada H.Yusri. Namun Allah berkehendak lain, konsep doa belum selesai dan bentuk hurufnya sulit dibaca, secara tiba-tiba dan tanpa adanya gejala terlebih dahulu, beliau jatuh sakit. Pada saat yang tidak begitu lama, tidak beberapa jam setelah itu beliau menghembuskan nafas terakhirnya, dijemput oleh Yang Maha Kuasa. Berita duka itu cepat meluas karena pagi harinya para pejabat pemerintah sedang menyambut dan menghadiri acara dengan bapak Menteri Bustamil Arifin, yang akhirnya menyebabkan suasana yang sudah direncanakan semarak berubah menjadi berita duka menyelumuti para hadirin. Berita duka itu menyelimuti dan dirasakan sebagian anggota masyarakat kareana kiprah dan kepribadiannya sebagai "pejabat yang merakyat" mengantarkan figur H.Yusri Anwar tidak mudah dilupakan begitu saja. Telah banyak jasa dan pengorbanan, ikut serta mendirikan madrasah serta semaraknya kehidupan religius menyebabakan masyarakat merasa kehilangan (Mulyadi, 2005:).

Rasa sedih dan duka yang mendalam menyelimuti keluarga besar MTI terhadap kepergian almarhum. Hal tersebut sangatlah beralasan karena sosok beliau sangat diharapkan untuk mengembangkan dan mengibarkan semarak MTI yang baru beberapa tahun dibuka kembali. Harapan besar itu sangat dirasakan oleh keluarga besar MTI Tabek Gadang karena beliau sangat dibutuhkan, dan masih banyak usaha dan niatnya yang belum terwujud. Tapi hal ini tidak membuat tokoh-tokoh dan buya-buya lainnya jadi patah semangat dan berusaha melanjutkan ide dan insiatif $\mathrm{H}$. Yusri Anwar.

Setelah beberapa bulan kepergian almarhum, implementasi tersebut sudah mulai terlihat, terutama usaha untuk mengembangkan MTI. Kehadiran madrasah ini diharapkan dapat memberikan angin segar di tengah-tengah masyarakat.

\section{Khatib Dt Ketumanggungan}

Khatib Dt Katumenggungan merupakan salah satu alumni MTI Tabek Gadang. Waktu MTI ini berhenti beroperasi, ia bersama Yursi Anwar dan beberapa orang lainnya berusaha untuk kembali menghidupkannya proses pembelajaran. Dalam struktur kepengurusan madrasah ini diawal berdirinya kembali ia diamanahi memegang tampuk kepemimpinan.

Usaha yang dilakukan adalah bagaimana mendatangkan agar santri meningkat dari tahun ke tahun. Sejalan dengan itu juga dilakukan usaha meningkatkan meningkatkan kualitas pembelajaran. Pembelajaran merupakan perpaduan kurikulum ketarbiyahan yang mengkaji ilmu agama Islam melalui kitab kuning atau kitab gundul dengan materi pembelajaran umum yang di waktu itu belum secara keseluruhan. Kemudian pemerintah melalui Departemen Agama memberikan izin dan membolehkan madrasah ini untuk menyelenggarakan pendidikan tingkat 
Tsanawiyah dan tingkat Aliyah, sehingga alumni sekolah ini sama peluangnya dengan madrasah lainnya untuk melanjutkan ke jenjang pendidikan yang lebih tinggi (Mulyadi, 2005). Faktor kesehatan yang tidak memungkinkan untuk melanjutkan amanah yang diembankan. Setelah lebih kurang 2 tahun memimpin MTI Tabek Gadang, Khatib Dt Katumenggungan mengundurkan diri.

\section{Suhaimi Abdul Wahid}

Suhaimi Abdul Wahid adalah anak dari Syekh Abdul Wahid dari istri yang bernama Jawa berasal dari Koto Tangah Simalanggang, dan sebelumnya hidup di perantauan. Setelah kembali ke Tabek Gadang beliau diminta untuk memimpin Sekolah ini. Pada usia yang hampir senja beliau memberikan sumbangan pemikiran demi pengembangan MTI. Belum sempat berbuat banyak, beliau dipanggil oleh Allah Yang Maha Kuasa untuk menghadap-Nya. ${ }^{5}$

\section{Imam Danoer}

Untuk memimpin MTI selanjutnya, pihak Yayasan dan segenap unsur MTI menunjuk Buya Imam Danoer sebagai pimpinan Madrasah. Beliau adalah anak didik Syarkawy Abdul Wahid dan merupakan salah seorang alumni MTI Tabek Gadang tahun 1950 an. Pada masa kepemimpinan Imam Danoer berbagai usaha untuk memajukan yayasan dan skolah terus di usahakan.

\section{Yuhamdi Yusri}

Drs. Yuhamdi Yusri adalah cicit dari Syekh Abdul Wahid, dan putra Yusri Anwar. Peran Yuhamdi Yusri di MTI Tabek Gadang adalah sebagai pelaksana tugas pengurus yayasan di kampung halaman. Meskipun beliau tidak banyak mengikuti pendidikan formal yang bersifat keagamaan tetapi pola pendidikan keluarga yang Islami mengantarkan beliau mempunyai perhatian dan kecenderungan terhadap kegiatan sosial, pendidikan, masyarakat yang mewarnai aktivitas keseharian beliau.

Banyak usaha dan langkah-langkah positif yang telah beliau sumbangkan, dan secara bertahap MTI mulai terlepas dari keterpurukan dan pemasalahan yang dihadapi. Solusi-solusi terhadap permasalahan yang mengapung ke permukaan diusahakan pemecahannya. Yuhamdi sangat menganggap penting mewadahi dan menyalurkan potensi yang dimiliki siswa untuk mewujudkan peserta didik yang kreatif dan inovatif. Untuk mewujudkan hal tersebut pihak lembaga didorong agar memberikan dan menyediakan fasilitas, terutama kegiatan-kegiatan yang sifatnya mengembangkan bakat dan minat, olahraga dan seni yang kesemuanya diberikan nuansa-nuansa yang Islami. Berbagai macam aktifitas tersebut diharapkan dapat mendorong madrasah yang lebih maju.

\footnotetext{
${ }^{5}$ Wawancara dengan Nasri Bey pada bulan Juni 2013 di Sipingai
} 
Ajal di tangan Allah, mendekati usia 40-an disaat kematangan dalam berpikir dan bersemangat untuk bekerja keras, Yuhamdi dipanggil Yang Maha Kuasa keharibaannya. Berkaitan dengan meninggalnya Yuhamdi Yusri, Mulyadi (2005) menuliskan :

"Pada awalnya banyak pihak yang tidak percaya atas kepergian beliau untuk selamanya, karena tidak ada tanda beliau akan pergi sesegera itu. Raut wajahnya selalu ceria dan simpatik bahkan perhatian dan kecenderungannya terhadap kegiatan-kegiatan kesiswaan lebih bergairah dan bersemangat. Kata-kata dan sifat kebapakan serta kecintaannya terhadap MTI lebih menonjol dari hari-hari biasanya. Banyak pesan, kesan, dan butiran hikmah yang beliau sampaikan.

Menyikapi fenomena tersebut menjadikan pihak yayasan dan pihak MTI diselimuti rasa duka yang mendalam. Komplek MTI terasa sepi, aktifitas belajar mengajar belum terasa bergairah, karena beliau merupakan ujung tombak dan lokomotif pengembangan Madrasah Tarbiyah Islamiyah Tabek Gadang, serta tenaga dan pemikiran beliau masih dibutuhkan. Setelah beberapa bulan sepeninggal almarhum pihak yayasan dan lembaga terus berbenah dalam usaha melanjutkan cita-cita yang telah beliau rintis. Setelah beberapa tahun kemudian perhatian pemerintah dan yayasan semakin tertuju untuk mengembangkan madrasah ini baik kualitas maupun dari segi kuantitas.

\section{Mulyadi}

Mulyadi ditunjuk menjadi kepala MTI Tabek Gadang pada tahun 2006, dan Ia merupakan alumni IAIN Imam Bonjol Padang tahun 2001. Mulyadi mulai mengabdi di MTI Tabek Gadang pada tahun 2001 sebagai tenaga pengajar. Enam bulan kemudian diangkat membidangi kesiswaan dan kepala unit usaha cabang Sumatera Barat. Pada masa kepemimpinan Mulyadi pembangunan fisik maupun non fisik terus diusahakan.

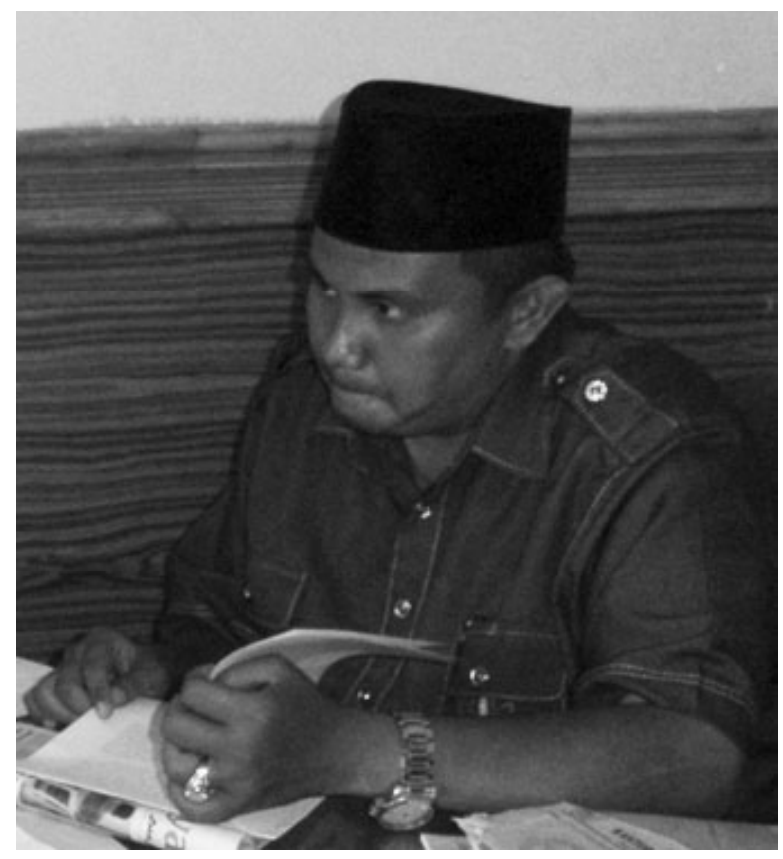

Gambar: 4

Mulyadi, S.Ag, Kepala MTI Tabek Gadang 2006-Sekarang 


\section{PENUTUP}

Pimpinan MTI Tabek Gadang telah silih berganti, mayoritas pergantian karena pemimpin sebelumnya meninggal dunia, dan nampaknya tidak ada ketentuan berapa lama satu periode kepemimpinan. Hal ini tentu saja dilatari oleh bentuk manajemen Madrasah Tarbiyah Islamiyah yang bercirikan klasik. Sosok pimpinan dalam madrasah-madrasah bercirikan tradisional atau klasik menjadi figur sentral dalam memajukan madrasah yang dipimpinnya. Para pimpinan MTI Tabek Gadang terdiri dari keturunan Syekh Abdul Wahid, cucu dan cicit. Disamping itu, beberapa orang alumi MTI Tabek Gadang juga pernah memimpin sekolah ini.

\section{DAFTAR PUSTAKA}

Iskandar, Mohammad,2001. Para Pengemban Amanah, Pergulatan Pemikiran Kiai dan Ulama di Jawa Barat, 1900-1950, Yogyakarta: Mata Bangsa.

Kusmayadi dkk, 2000. Metodologi Penelitian dalam Bidang Kepariwisataan, Jakarta: PT Gramedia Pustaka Utama.

Kanagarian VII Koto Talago, 2010, Data Potensi Nagari. Tidak ditrebitkan

Martin Van Bruinessen, 1995. Kitab Kuning , Pesantren dan Tarekat: Tradisi-tradisi Islam di Indonesia, Bandung: Mizan

Mawardi, Erman, 2011. Profil Tujuah Koto Talago, Bandung: CV Alfabeta

Mulyadi, 2005. Sekilas Syekh Abdul Wahid Ashshalihy dan MTI Tabek Gadang, tidak diterbitkan.

Nata, Abudin, 2009. Metodologi Studi Islam, Jakarta: PT Raja Grafindo

Nizar, Syamsul, 2008. Memperbincangkan Dinamika Intelektual dan Pemikiran Hamka tentang Pendidikan Islam, Jakarta: Kencana

Nyoman Kutha Ratna, 2010. Metodologi Penelitian, Kajian Budaya dan Ilmu Sosial Humaniora Pada Umumnya, Yogyakarta: Pustaka Pelajar

Sagimun MD, 1993 “Mengapa Biografi” dalam pemikiran Biografi dan kesejarahan, Jakarta :Gramedia

S.Wiranta dan H.Hadisuwarno, 2007. Modul Diklat Fungsional Peneliti Tingkat Pertama, Cibinong: LIPI

Yunus, Mahmud, 1979. Sejarah Pendidikan Islam di Indonesia, Jakarta. 